\title{
PENINGKATAN HASIL BELAJAR MATERI KAIDAH FUNDAMENTAL BANGSAKU DENGAN TEKNIK JIGSAW DI SMAN I GADING
}

\author{
Luluk Hidayati
}

SMAN 1 Gading Kabupaten Probolinggo

\begin{abstract}
Abstrak: Tujuan penelitian yang ingin dicapai : (a) Pendeskripsian langkahlangkah dalam proses pembelajaran, (b) Menjelaskan peranan media gambar dalam membantu siswa dalam peningkatan kemampuan, (c) Menyempurnakan pelaksanaan pembelajaran PPKn. Penelitian ini menggunakan penelitian tindakan (action research) sebanyak dua Siklus, setiap putaran terdiri empat tahap ; perencanaan, pelaksanaan, observasi, refleksi. Data yang diperoleh berupa hasil tes dan lembar observasi kegiatan belajar mengajar, dari hasil analisis didapatkan perestasi belajar siswa mengalami peningkatan dari siklus I sampai siklus II ; siklus I $(51,5 \%)$ dan siklus II (85,5\%). Kesimpulan dari penelitian dengan metode pembelajaran model Jigsaw dapat berpengaruh positif tehadap prestasi dan motivasi belajar siswa kelas X MIA-3 SMAN 1 Gading, sehingga model pembelajan ini dapat digunakan sebagai salah satu alternatif pembelajaran PPKn
\end{abstract}

Kata kunci: hasil belajar, fundamental bangsaku, jigsaw.

Pendidikan Pancasila dan Kewargaan adalah salah satu wahana untuk mengembangkan dan melestarikan nilai-nilai luhur yang berakar pada budaya bangsa Indonesia yang diharapkan dapat diwujudkan dalam bentuk perilaku kehidupan sehari-hari.

Mata pelajaran PPKn merupakan mata pelajaran yang menfokuskan pada pembentukan warga negara yang memahami dan mampu melaksanakan hak-hak dan kewajibannya untuk menjadi waga negara Indonesia yang cerdas, terampil, dan berkarakter yang diamanatkan oleh Pancasila dan UUD 1945.

Mata pelajaran PPKn disekolah bertujuan untuk mengembangkan pengetahuan dalam mamahami dan menghayati nilai-nilai Pancasila dalam membentuk sikap dan prilaku sebagai pribadi, anggota masyarakat, dan warga negara yang bertanggung jawab serta memberi bekal kemampuan untuk mengikuti pendidikan pada jenjang berikutnya, untuk itu perlu penanamaan fundamental bangsaku yang kuat pada diri waga negaranya yang telah tertuang dalam; Pembukaan Undang-undang Dasar, Isi dan Pokok Pikiran Pembukaan Undang-Undang Dasar Negara Republik Indonesia Tahun 1945, Cita-Cita Dan Tujuan Nasional Berdasarkan Pancasila, Kedaulatan Rakyat dalam Konteks Negara Hukum.

Model pembelajaran Jigsaw adalah salah satu model pembelajaran kooperatif. Jigsaw pertama kali dikembangkan dan diuji coba oleh Elliot dkk di Universitas Texas, kemudian diadaptasi oleh Slavin dkk di Universitas John Hopkins (Arends, dalam Kuntjojo dkk; 2011: 20). Pembelajaran kooperatif model Jigsaw ini siswa melakukan suatu kegiatan belajar dengan cara bekerja sama dengan siswa lain untuk mencapai tujuan bersama. Pembelajaran kooperatif Jigsaw merupakan salah satu tipe pembelajaran kooperatif yang mendorong 
siswa aktif dan saling membantu dalam menguasai materi pelajaran untuk mencapai prestasi yang maksimal (Isjoni, 2010: 54). Dalam model pembelajaran Jigsaw ini siswa memiliki banyak kesempatan untuk mengemukakan pendapat, dan mengolah informasi yang didapat dan dapat meningkatkan keterampilan berkomunikasi. Anggota kelompok bertanggung jawab atas keberhasilan kelompoknya dan ketuntasan bagian materi yang dipelajari, dan dapat menyampaikan kepada kelompoknya.

Tujuan pembelajaran kooperatif tipe Jigsaw pada intinya adalah memberikan rasa tanggung jawab individu dan kelompok untuk keberhasilan bersama dan untuk saling berinteraksi dengan kelompok lain. Menurut Slavin (2005 : 121) tujuan pembelajaran tipe Jigsaw adalah menciptakan situasi dimana keberhasilan individu ditentukan oleh keberhasilan kelompoknya. Sistem ini berbeda dengan kelompok konvensional yang menerapkan sistem kompetisi dimana keberhasilan individu diorientasikan pada kegagalan orang lain.Untuk itu, kekompakan dan dan kerja sama yang solid antar kelompok menentukan berhasil dan tidaknya pembelajaran tersebut karena satu sama lain akan memberikan informasi yang telah didapat dari kelompok lain.

Model pembelajaran Jigsaw didesain untuk meningkatkan rasa tanggung jawab siswa terhadap pembelajarannya sendiri dan juga pembelajaran orang lain. Siswa tidak hanya mempelajari materi yang diberikan, tetapi mereka juga siap memberikan dan mengajarkan materi tersebut pada anggota kelompoknya yang lain. Dengan demikian, siswa saling ketergantungan satu dengan yang yang lain dan harus bekerjasama secara kooperatif untuk mempelajari materi yang ditugaskan

\section{METODE}

\section{Pendekatan Penelitian dan Jenis Penelitian}

Pendekatan yang digunakan pada penelitian ini pendekatan deskriptif kualitatif yaitu penelitian yang menggambarkan bagaimana suatu model pembelajaran diterapkan dan bagaimana hasil yang diharapkan dapat tercapai. dengan jenis Penelitian Tindakan Kelas (PTK) atau yang dikenal dengan Classroom Action Research, yang berarti action research (penelitian dengan tindakan) yang dilakukan dikelas. Arikunto, dkk (2010: 2) menjelaskan pengertian PTK secara lebih sistematis yaitu: (1) penelitian adalah kegiatan mencermati suatu objek dengan menggunakan cara dan aturan tertentu untuk menemukan data akurat tentang hal-hal yang dapat meningkatkan mutu objek yang diamati, (2) tindakan adalah gerakan (siklus-siklus kegiatan untuk siswa) yang dilakukan dengan sengaja dan terencana dengan tujuan tertentu, dan (3) kelas adalah tempat dimana terdapat sekelompok siswa yang dalam waktu bersamaan menerima pelajaran dari guru yang sama.

Pengertian diatas dapat diartikan bahwa yang dimaksud dengan PTK adalah pencermatan terhadap kegiatan belajar berupa sebuah tindakan, yang sengaja dimunculkan dan terjadi dalam sebuah kelas secara bersamaan. Penelitian tindakan kelas termasuk penelitian kualitatif (qualitatif reseacrh). "Penelitian kualitatif adalah penelitian yang menggunakan latar alamiah, dengan maksud menafsirkan fenomena yang terjadi dan dilakukan dengan jalan melibatkan 
berbagai metode yang ada”. Denzin dan Lincoln (dalam Lexy J.Moleong 2004:5) Beberapa deskripsi digunakan untuk menemukan prinsip-prinsip dan penjelasan yang mengarah pada penyimpulan. Beberapa ahli yang mengemukakan model penelitian tindakan dengan bagan yang berbeda, namun secara garis besar terdapat empat tahapan yang lazim dilalui, yaitu: (1) perencanaan, (2) pelaksanaan, (3) pengamatan, dan (4) refleksi (Arikunto dkk , 2010:16).

Penelitian ini menggunakan bentuk penelitian tindakan kolaboratif, dimana peneliti bertindak sebagai guru sedangkan Guru PPKn yang lainnya dalam satu sekolah sebagai pengamat (observer). Penelitian ini bertujuan untuk mendeskripsikan penerapan pembelajaran kooperatif model Jigsaw, mengetahui respon siswa tentang pembelajaran yang menggunakan kooperatif model Jigsaw dan apakah penerapan model pembelajaran kooperatif Jigsaw dapat meningkatkan hasil belajar siswa pada mata pelajaran PPKn khususnya dalam materi Fundamintal Bangsaku.

Peneliti menggunakan model PTK yang dikembangkan oleh Kemmis dan Taggart (1990), peneliti menggunakan beberapa tahapan mulai dari perencanaan, pelaksanaan, pengamatan, dan refleksi seperti yang dijelaskan oleh Arikunto ( 2010: 17). Tahapan yang dilaksanakan oleh peneliti secara lebih rinci sebagai berikut. Tahap perencanaan kegiatan yang dilakukan peneliti adalah menyusun rancangan untuk menentukan langkah-langkah yang akan dilakukan dalam tindakan. Perencanaan tersebut meliputi pengkajian Standar Kompetensi dan Kompetensi Dasar, penyusunan RPP, penetapan target keberhasilan pembelajaran dan membuat instrument pengamatan untuk merekam fakta yang terjadi selama proses pembelajaran.

Pelaksanaan tindakan penelitian ini dilaksanakan dalam dua siklus, masing-masing siklus terdiri atas dua pertemuan. Tahap rancangan yang dilaksanakan dalam tahap pelaksanaan menjelaskan mengenai langkah-langkah kegiatan yang harus dilakukan oleh guru dan siswa untuk meningkatkan hasil belajar PPKn materi pokok kaidah pundamental bangsaku melalui model pembelajaran Jigsaw.

Tahap ketiga dalam PTK adalah pengamatan. Pengamatan atau observasi yang dimaksud pada tahap III adalah pengumpulan data. Dalam proses pengumpulan data, peneliti melakukan pengamatan dan mencatat semua hal yang terjadi selama pelaksanaan kegiatan berlangsung untuk memperoleh data yang akurat untuk perbaikan siklus selanjutnya. Kegiatan pengamatan atau observasi dilaksanakan secara kolaboratif untuk mengamati keterampilan guru, serta hasil belajar siswa pada mata pelajaran PPKn materi pokok kaidah pundamental bangsaku dengan model pembelajaran Jigsaw.

Pada tahap refleksi peneliti melakukan evaluasi terhadap apa yang telah dilakukan. Selain itu peneliti juga menganalisis kekurangan pada pelaksanaan pembelajaran yang telah dilakukan untuk diperbaiki pada siklus selanjutnya sampai masalah yang diteliti dapat dipecahkan secara optimal.

\section{HASIL}

Pada siklus I diperoleh temuan sebagai berikut (1) aktivitas guru dalam menerapkan langkah-langkah pembelajaran menggunakan model Jigsaw 
memperoleh peningkatan nilai yaitu pada pertemuan 1 sebesar $63 \%$ dan meningkat menjadi 74\% pada pertemuan 2, (2) pemahaman siswa tentang Materi Pokok Kaidah Fundamental Bangsaku masih kurang baik, (3) beberapa siswa yang belum mau untuk berpartisipasi dalam kelompok, (4) masih terdapat beberapa siswa yang ramai, (5) siswa masih ragu dan kurang berani untuk bertanya jawab dengan guru atau menyampaikan kesan atau pendapat, (6) hasil belajar siswa pada siklus I pertemuan 1 menunjukkan nilai rata-rata kelas yakni 64 dan pada siklus I pertemuan 2 meningkat menjadi 71 dan rata-rata persentase nilai akhir ketuntasan belajar siswa pada siklus I pertemuan 1 sebesar $45 \%$ dan siklus I pertemuan 2 sebesar 58\%, sehingga pada penilaian akhir ketuntasan belajar siswa memperoleh peningkatan.

Pada siklus II diperoleh temuan sebagai berikut: (1) aktivitas guru dalam menerapkan langkah-langkah pembelajaran menggunakan model Jigsaw memperoleh peningkatan nilai yaitu pada pertemuan 1 sebesar $86 \%$ dan meningkat menjadi 97\% pada pertemuan 2, (2) pemahaman siswa tentang Materi Pokok Kaidah Fundamental Bangsaku baik, (3) tidak ada siswa yang tidak mau untuk berpartisipasi aktif dalam kelompok, (4) tidak ada siswa yang ramai sendiri, (5) siswa sudah berani untuk bertanya jawab dengan guru, tetapi belum berani mengungkapkan kesan saran, (6) hasil belajar siswa pada siklus II pertemuan 2 menunjukkan nilai rata-rata kelas pada pada siklus II pertemuan 1 yakni 75 dan pada siklus II pertemuan 2 meningkat menjadi 82 dan rata-rata persentase nilai akhir ketuntasan belajar siswa pada siklus pertemuan 1 sebesar $77 \%$ dan siklus pertemuan 2 sebesar 92\%, sehingga pada penilaian akhir ketuntasan belajar siswa memperoleh peningkatan.

\section{PEMBAHASAN}

Berdasarkan observasi, model pembelajaran Jigsaw telah dilaksanakan sesuai dengan langkah-langkah pada rencana pelaksanaan pembelajaran. Temuan aktivitas guru pada pelaksanaan tindakan siklus I yaitu guru telah melaksanakan pembelajaran dengan cukup baik salah satunya adalah guru menjelaskan kegiatan pembelajaran yang akan dilakukan. Guru juga memberikan motivasi kepada siswa agar selalu bersemangat dalam belajar. Hal ini dilakukan untuk menyiapkan dan membimbing siswa agar terlibat aktif dalam pembelajaran dan siswa memiliki motivasi dalam diri mereka untuk belajar sehingga keberhasilan dalam belajar dapat tercapai. Menurut Dimyati dan Mudjiono (2002:43) menjelaskan bahwa motivasi merupakan faktor seperti halnya intelegensi dan hasil belajar sebelumnya yang dapat menentukan keberhasilan belajar siswa dalam bidang pengetahuan, nilai-nilai dan keterampilan. Berdasarkan pendapat tersebut motivasi serta penjelasan guru mengenai kegiatan pembelajaran PPKn melalui model Jigsaw yang akan dilaksanakan sangatlah penting bagi siswa agar siswa jelas dengan kegiatan yang direncanakan oleh guru.

Pembelajaran yang dilaksaakan pada siklus I dan siklus II sesuai dengan Rencana Pelaksanaan Pembelajaran (RPP) yang telah disusun. Secara garis besar, pembelajaran pada siklus I dan sklus II dapat diringkas yaitu: (1) guru memberikan penjelasan dan memberikan soal beserta penyelesaiannya, (2) siswa membentuk kelompok asli dan diberi tugas menyelesaikan soal sesuai dengan 
nomor anggota yang diterimanya,(3 ) siswa membentuk kelompok baru yakni kelompok ahli yang memiliki kode soal sama, berdiskusi untuk menyelesaikan soal yang diterima, (4) siswa kembali ke kelompok asli masing-masing untuk bergantian menjelaskan jawaban serta cara penyelesaian dari soal yang telah di diskusikan dengan kelompok ahli sebelumnya, (5) siswa menyelesaikan tes atau evaluasi di akhir kegiatan secara individu.

Penerapan model pembelajaran Jigsaw pada mata pelajaran PPKn materi Pokok pikiran yang terkandung dalam Pembukaan Undang-Undang Dasar 1945 pada siklus I sudah berjalan dengan lancar. Guru sudah cukup baik dalam pelaksanaan pembelajaran sesuai dengan RPP yang telah dibuat sebelumnya. Namun masih ada beberapa langkah pembelajaran yang belum dilaksanakan. Dari hasil yang telah diperoleh aktivitas guru pada siklus I pertemuan 1 memperoleh presentase sebesar $63 \%$ dan pada siklus I pertemuan 2 memperoleh presentase sebesar 74\%, sehingga pada siklus I ketuntasan aktivitas guru mendapatkan ratarata presentase sebesar $68,5 \%$.

Sedangkan dari aktivitas pembelajaran siswa pada siklus I, keaktifan siswa dalam pembelajaran sudah mulai muncul. Dari data yang diperoleh menunujukan presentase aktivitas siswa pada siklus I pertemuan 1 memperoleh presentase sebesar $40 \%$ dan pada siklus I pertemuan 2 memperoleh presentase sebesar $60 \%$, sehingga pada siklus I aktivitas siswa memperoleh presentase rata rata sebesar 50\%. Hal ini menunjukkan bahwa 50\% siswa telah menunjukkan aktivitas yang positif pada siklus I ketika diterapkan model pembelajaran Jigsaw.

Hasil belajar siswa dalam pelaksanan siklus I diketahui masih cukup banyak siswa yang belum mencapai KKM yang telah ditentukan mencapai nilai $\geq$ 70. Dari 31 siswa dalam kelas pada siklus I pertemuan 1 terdapat 14 siswa (45\%) yang sudah tuntas dan 17 siswa $(55 \%)$ yang tidak tuntas, pada siklus I pertemuan 2 terdapat 18 siswa (58\%) yang sudah tuntas dan $13(42 \%)$ siswa yang tidak tuntas.

Dari hasil yang telah diperoleh aktivitas guru pada siklus II menunujukan bahwa guru telah melaksanakan langkah-langkah pembelajaran dengan sangat baik. Hal ini ditunjukkan dengan perolehan presentase aktivitas guru siklus II pada pertemuan 1 sebesar $86 \%$ dan pada siklus II pertemuan 2 memperoleh presentase sebesar 97\%, sehingga pada siklus II aktivitas guru mendapatkan rata-rata presentase sebesar $91,5 \%$.

Sedangkan dari aktivitas pembelajaran siswa pada siklus II, keaktifan siswa dalam pembelajaran sudah muncul. Dari data yang diperoleh menunujukan presentase aktivitas siswa pada siklus II pertemuan 1 memperoleh presentase sebesar $80 \%$ dan pada siklus II pertemuan 2 memperoleh presentase sebesar $90 \%$, sehingga pada siklus I aktivitas siswa memperoleh presentase rata - rata sebesar $85 \%$. Hal ini menunjukkan bahwa siswa telah menunjukkan aktivitas yang lebih positif pada siklus II ketika diterapkan model pembelajaran Jigsaw.

Hasil belajar siswa dalam pelaksanan siklus II diketahui hampir seluruh siswa mencapai KKM yang telah ditentukan mencapai nilai $\geq 70$. Dari 31 siswa dalam kelas pada siklus II pertemuan 1 terdapat 24 siswa (77\%) yang sudah tuntas dan 7 siswa (23\%) yang tidak tuntas pada siklus II pertemuan 2 terdapat 29 siswa (94\%) siswa yang sudah tuntas dan 2 siswa (6\%) yang tidak tuntas. Hal ini 
menunjukkan adanya peningkatan jika dibandingkan dengan perolehan hasil pada siklus I.

Berdasarkan temuan dari yang diperoleh dari aktivitas guru dan aktivitas siswa maka dapat disimpulkan bahwa penerapan model pembelajaran Jigsaw dapat meningkatkan hasil belajar PPKn materi Pokok Kaidah Fundamental Bangsaku pada siswa kelas X MIA-3 SMA Negeri I Gading Kecamatan Gading Kabupaten Probolinggo.

\section{KESIMPULAN SARAN}

Dari hasil kegiatan pembelajaran yang telah dilakukan selama dua siklus, dan berdasarkan seluruh pembahasan serta analisis yang telah dilakukan dapat disimpulkan sebagai berikut: (1) Pembelajaran dengan metode Cooperative Learning teknik Jigsaw memiliki dampak positif dalam meningkatkan mutu belajar siswa. Hal ini dapat dilihat dari semakin mantapnya pemahaman siswa terhadap materi yang disampaikan guru ( rata-rata prosentase ketuntasan belajar meningkat dari sklus I dan II ) yaitu masing-masing 51,5\%, dan 85,5\%. (2) Adanya peningkatan hasil belajar siswa dipengaruhi oleh adanya peningkatan kemampuan guru dalam menerapkan pembelajaran metode Cooperative Learning teknik Jigsaw sehingga siswa menjadi lebih terbiasa dengan pembelajaran seperti ini dan memiliki tingkat inovasi dalam pembelajaran yang lebih tinggi sehingga siswa lebih mudah dalam memahami materi yang telah diberikan serta mampu memecahkan sendiri masalah yang didahapi pada saaat pembelajaran.

\section{SARAN}

Dari hasil penelitian yang diperoleh dari uraian sebelumnya agar proses belajar mengajar PKn lebih efektif dan lebih memberikan hasil yang optimal bagi siswa, maka disampaikan saran sebagai berikut: (1) Untuk melaksanakan metode Cooperative Learning teknik Jigsaw memerlukan persiapan yang cukup matang, sehingga guru harus mampu menguasai dan mengkondisikan siswa dalam kelas agar dapat mencapai kesuksesan dalam penerapan metode dan siswapun lebih memiliki tingkat inovasi dalam pembelajaran dan mampu mencapai ketuntasan dalam belajar, (2) Dalam rangka meningkatkan mutu belajar siswa, guru hendaknya lebih sering melatih siswa dengan berbagai macam metode pembelajaran walau dalam taraf yang sederhana, siswa nantinya dapat menemukan pengetahuan baru, memperoleh konsep dan keterampilan, sehingga siswa berhasil atau mampu memecahkan masalah-masalah yang dihadapinya.

\section{DAFTAR RUJUKAN}

Arends. 1997. Langkah-langkah Model Pembelajaran Jigsaw. (online) (www.asikbelajar.com/2012/11/model-pembelajaran-jigsaw.html?m=) diaksestanggal 22 November 2014.

Dimyati dan Mudjiono. 2002. Belajardan Pembelajaran. Jakarta : PT Rineka Cipta. 
Moleong, J Lexy.2004 Metodologi Penelitian Kualitatif. Bandung : PT Remaja Rosda karya.

Slavin, E Robert. 2005. Cooperative Learning. Bandung : Penerbit Nusa Media.

Arikunto, Suharsimi, dkk. 2006. PenelitianTindakanKelas. Jakarta: BumiAksara.

Slavin dkk di Universitas John Hopkins (Arends, dalam Kuntjojo dkk; 2011: 20).

H.M Zainuddin. 2012. Membentuk Karakter Anak Bangsa. Malang : UM Press.

Isjoni. 2009. PembelajaranKooperatif. Yogyakarta : PustakaPelajar.

Isjoni. 2010. Cooperative Learning. Yogyakarta : Pustaka Pelajar. 